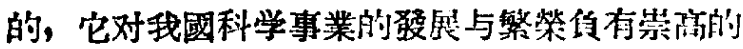

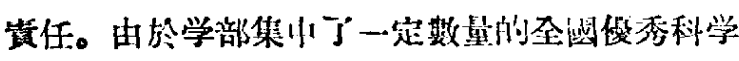
综，学部本身攵是学術上民主的集体組織，我佃 認䉆, 只要每個学部和每位寥加学部工作的学部 委員，經常關心本門科学活動情况和存在的問題， 㴽切注意有關部門科学的菠展方向, 廣泛联系和 因結有關部門的科学家，充分弡拝学部工作上的 集体領基作用, 学部的工作任務是可以順利開展 的。

同志們，我們的國家正在做着我們的前人从 來汥有做过的極其偉大的事媇。我們中國人民以 有中國共産党和偉大的科学家、思想家毛濢东主
席的領獎而感到光㮡。我們感謝党和政俯維予了

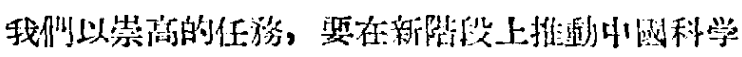

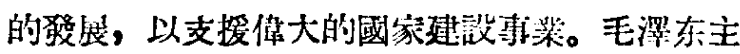

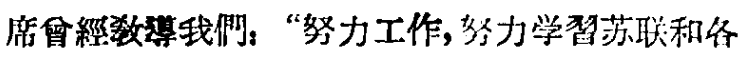
兄弟國家的先進經驗, 老老实实, 勤勤怒愁, 互

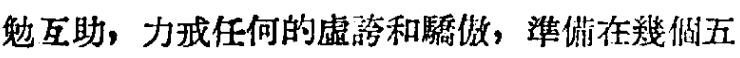
年計部之內，将我們現在这樣一個經流上文化： 落後的國家，建設成篇一個工業化的具有陾度文

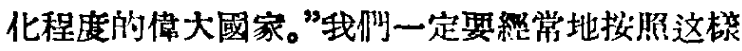
做，在馬克思列蜜主義的旗幟之下，和全國人民

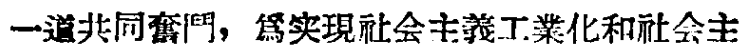
義改造和促進中國科学的發提而作不浄的努力。

\title{
朝鮮民主主義人民共和國科学院致中國 科学院学部成立大会的賀電
}

\section{中華人民共和國科学院}

院長部体若先生

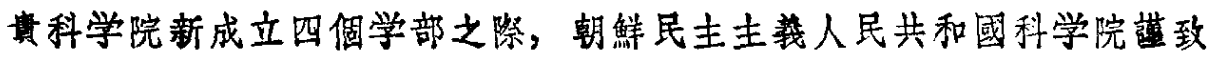
积贺。 